\title{
Effect of nanoparticles binding $\beta$-amyloid peptide on nitric oxide production by cultured endothelial cells and macrophages
}

This article was published in the following Dove Press journal:

International Journal of Nanomedicine

II April 2013

Number of times this article has been viewed

\author{
Antonina Orlando' \\ Francesca $\operatorname{Re}^{1}$ \\ Silvia Sesana' \\ Ilaria Rivolta' \\ Alice Panariti' \\ Davide Brambilla ${ }^{2}$ \\ Julien Nicolas ${ }^{2}$ \\ Patrick Couvreur ${ }^{2}$ \\ Karine Andrieux ${ }^{2}$ \\ Massimo Masserini' \\ Emanuela Cazzaniga' \\ 'Department of Health Sciences, \\ University of Milano-Bicocca, \\ Monza, Italy; ${ }^{2}$ Institut Galien \\ Paris Sud, University Paris-Sud, \\ Châtenay-Malabry, France
}

Correspondence: Francesca Re Department of Health Sciences, University of Milano-Bicocca, via Cadore 48, 20900 Monza, Italy

$\mathrm{Tel}+390264488228$

Fax +390264488068

Email francesca.rel@unimib.it
Background: As part of a project designing nanoparticles for the treatment of Alzheimer's disease, we have synthesized and characterized a small library of nanoparticles binding with high affinity to the $\beta$-amyloid peptide and showing features of biocompatibility in vitro, which are important properties for administration in vivo. In this study, we focused on biocompatibility issues, evaluating production of nitric oxide by cultured human umbilical vein endothelial cells and macrophages, used as models of cells which would be exposed to nanoparticles after systemic administration.

Methods: The nanoparticles tested were liposomes and solid lipid nanoparticles carrying phosphatidic acid or cardiolipin, and PEGylated poly(alkyl cyanoacrylate) nanoparticles (PEGPACA). We measured nitric oxide production using the Griess method as well as phosphorylation of endothelial nitric oxide synthase and intracellular free calcium, which are biochemically related to nitric oxide production. MTT viability tests and caspase-3 detection were also undertaken.

Results: Exposure to liposomes did not affect the viability of endothelial cells at any concentration tested. Increased production of nitric oxide was detected only with liposomes carrying phosphatidic acid or cardiolipin at the highest concentration $(120 \mu \mathrm{g} / \mathrm{mL})$, together with increased synthase phosphorylation and intracellular calcium levels. Macrophages exposed to liposomes showed a slightly dose-dependent decrease in viability, with no increase in production of nitric oxide. Exposure to solid lipid nanoparticles carrying phosphatidic acid decreased viability in both cell lines, starting at the lowest dose $(10 \mu \mathrm{g} / \mathrm{mL})$, with increased production of nitric oxide detected only at the highest dose $(1500 \mu \mathrm{g} / \mathrm{mL})$. Exposure to PEG-PACA affected cell viability and production of nitric oxide in both cell lines, but only at the highest concentration $(640 \mu \mathrm{g} / \mathrm{mL})$.

Conclusion: Liposomal and PEG-PACA nanoparticles have a limited effect on vascular homeostasis and inflammatory response, rendering them potentially suitable for treatment of Alzheimer's disease. Moreover, they highlight the importance of testing such nanoparticles for production of nitric oxide in vitro in order to identify a therapeutic dose range suitable for use in vivo.

Keywords: nanoparticles, nitric oxide, endothelial cells, macrophages, Alzheimer's disease

\section{Introduction}

In previous studies carried out within the framework of a project designing nanoparticles for the diagnosis and treatment of Alzheimer's disease (http:/www.nadproject.eu), a series of candidate nanoparticles (liposomes, solid lipid nanoparticles, poly-(alkyl cyanoacrylate) nanoparticles [PACA] ) binding with high affinity to $\beta$-amyloid (present in high amounts in the brains of patients with Alzheimer's disease) were synthesized and characterized in vitro. ${ }^{1-3}$ For this purpose, liposomes and solid lipid nanoparticles were functionalized with phosphatidic acid (PA-LIP and PA-SLN, respectively) or cardiolipin 
(CL-LIP), while PACA was decorated with poly-(ethylene glycol) chains (PEG-PACA). Testing of the biocompatibility of these nanoparticles in vitro is an essential step in order to anticipate and understand any problems which may arise during their in vivo administration, and some experiments in this direction have been already carried out. ${ }^{4,5}$ Given that these nanoparticles are likely to interact either with the cells lining the vascular bed or with cells circulating in the blood after administration in vivo, in this study we used cultured human umbilical vein endothelial cells (HUVECs) and mouse macrophages (RAW264.7) as cellular models in which to explore the biocompatibility issue.

The endothelium is a highly heterogeneous and widely disseminated tissue with a variety of functional properties, including control of vascular homeostasis and tone, which is partially maintained by the nitric oxide produced by the endothelial nitric oxide synthase (eNOS) enzyme. ${ }^{6}$ An increase in intracellular calcium ions induces phosphorylation of eNOS, increasing its activity, with consequent production of nitric oxide. ${ }^{7-10}$

With regard to interaction with macrophages, it has already been demonstrated that nanoparticles are taken up by these circulating cells both in vitro and in vivo. ${ }^{11,12}$ Macrophages have many important functions, ie, participating actively in host defense against infections by phagocytosis and killing of pathogens, and in inflammatory reactions. During the inflammatory response, macrophages release a number of proinflammatory mediators, including nitric oxide. ${ }^{13}$

For these reasons, in this study we evaluated the response of the cell, in terms of nitric oxide production, in combination with viability assays, upon exposure to PA-LIP, CL-LIP, PA-SLN, or PEG-PACA.

\section{Materials and methods Materials}

Commercial chemicals were used, and were of the highest available grade. Sphingomyelin from bovine brain, cholesterol, phosphatidic acid, cardiolipin, 3-(4,5-dimetiltiazol2-yl)-2,5-diphenyltetrazolium bromide (MTT), reagents for analysis of nitric oxide production, lipopolysaccharide (Escherichia coli 055:B5), resveratrol, and rabbit anti- $\beta$-actin antibody were sourced from Sigma-Aldrich (St Louis, MO, USA); Compritol 888ATO (glyceryl behenate) was from Gattefossè (Milan, Italy); Lutrol F68 (hydrophilic block copolymer of ethylene oxide and propylene oxide) was from BASF Corporation (Ludwigshafen, Germany); Phospholipon $80 \mathrm{H}$ (hydrogenated phosphatidylcholine, 60\%) was from
Phospholipid (Koln, Germany); and Pluronic F-68 (99\%) was from Sigma-Aldrich (St Quentin Fallavier, France). Acetone was purchased at the highest grade from Carlo Erba (Val de Reuil, France). The human umbilical vein endothelial cells used in this study were obtained from Lonza (Walkersville, MD, USA); the murine monocytic macrophage cell line (RAW264.7) was obtained from the American Type Culture Collection (LGC Partner, Milan, Italy); the EGM ${ }^{\text {тм}}-2$ SingleQuot kit used was from Lonza; all the stock solutions used for culture of the macrophages were from Euroclone (Milan, Italy); Fluo 4-AM was from Molecular Probes (Milan, Italy); mouse anti-eNOS, rabbit anti-eNOS, and mouse anticaspase-3 were from Cell Signaling (Beverly, MA, USA); secondary HRP-conjugated antibodies and ECL SuperSignal detection kit were from Pierce Biotechnology (Rockford, IL, USA); SDS-NuPAGE ${ }^{\circledR}$ reagents (4\%-12\% Bis-Tris gel; sample buffer; running buffer) and Precision Plus Protein Standard were from Invitrogen (Milan, Italy); and the complete protease inhibitor cocktail was from Roche (Grenzach-Wyhlen, Germany). Ultrapure and deionized water were obtained from a Direct-Q5n system (Millipore, Milan, Italy). All other chemicals were reagent grade.

\section{Preparation and characterization of nanoparticles}

The liposomes and PACA used had been previously prepared and characterized, ${ }^{1,2}$ while the solid lipid nanoparticles were developed and characterized in the present work.

\section{Liposomes}

Liposomes, composed of a matrix of sphingomyelincholesterol (1:1 molar ratio) mixed or not with 5 molar percent of phosphatidic acid or cardiolipin, were prepared according to an extrusion procedure which has been described previously. ${ }^{1}$ Liposomes composed of sphingomyelin-cholesterol are referred to here as "plain liposomes". Briefly, lipids were dissolved in chloroform/methanol $(2: 1, \mathrm{v}: \mathrm{v})$ and dried using a vacuum pump to remove any traces of the organic solvent. The resulting lipid film was rehydrated in $10 \mathrm{mM}$ phosphate-buffered saline ( $\mathrm{pH} 7.4$ ), vortexed, and extruded 10 times at $55^{\circ} \mathrm{C}$ through a stack of two polycarbonate filters $(100 \mathrm{~nm}$ pore size diameter, Millipore Corporation, Bedford, MA, USA) under 20 bar nitrogen pressure using an extruder (Lipex Biomembranes, Vancouver, Canada). The liposomes were characterized for size, polydispersity, zeta potential, and stability by dynamic laser light scattering using a ZetaPlus particle sizer and zera potential analyzer (Brookhaven Instruments Corporation, Holtsville, NY USA), as previously described. ${ }^{1}$ 


\section{Solid lipid nanoparticles}

Solid lipid nanoparticles were prepared using the meltemulsification process. ${ }^{14}$ The lipids Compritol 888ATO $(0.2 \%, \mathrm{w} / \mathrm{v})$ and Phospholipon $80 \mathrm{H}(0.1 \%, \mathrm{w} / \mathrm{v})$, were melted at approximately $10^{\circ} \mathrm{C}$ above their melting point. Next, $5 \mathrm{~mL}$ of heated steric stabilizer (Lutrol F68) solution, prepared in ultrapure water $(0.1 \%, \mathrm{w} / \mathrm{v})$, was added and stirred for 10 minutes at 12,000 rpm using a rotor-stator homogenizer (Ultra-Turrax $^{\circledR} \mathrm{T} 25$, Daigger Laboratory Equipment and Supplies, Vernon Hills, IL, USA) to yield a dispersion of small liquid droplets in water. This dispersion was diluted with $5 \mathrm{~mL}$ of cold Lutrol solution and cooled to room temperature (10 minutes of stirring at $5000 \mathrm{rpm})$. Under these conditions, the lipids solidified and particles were formed with a solid lipid core (Compritol 888ATO) having an outer layer composed of adsorbed phospholipid (Phospholipon) and steric stabilizer (Lutrol).

PA-SLN were prepared according to a method described previously ${ }^{14}$ with slight modifications, ${ }^{1}$ whereby $2.5 \%$ mol of Phospholipon $80 \mathrm{H}$ was substituted with phosphatidic acid. Phosphatidic acid was dissolved in chloroform/methanol $(2: 1, \mathrm{v}: \mathrm{v})$ and dried under a gentle stream of nitrogen followed by vacuum pumping for 3 hours to remove any traces of the organic solvent. The other lipids, Compritol 888ATO and Phospholipon $80 \mathrm{H}$, were then added and melted as described above. Being an amphiphilic molecule, phosphatidic acid localizes to the interphase of a microemulsion, allowing the negatively charged hydrophilic portion to remain exposed on the surface of the solid lipid nanoparticles. The solid lipid nanoparticles and PA-SLN were characterized for size, polydispersity index, and zeta potential as described above for the liposomes. Stability was measured in phosphate-buffered saline by observing the particle size and polydispersity index by dynamic laser light scattering for up to 48 hours.

\section{Poly-(alkyl cyanoacrylate) nanoparticles}

PACA (non-PEGylated, molecular weight $1000 \mathrm{~g} / \mathrm{mol}$ ) and PEG-PACA (molecular weight $3200 \mathrm{~g} / \mathrm{mol}$ ) nanoparticles were prepared according to previously published protocols using poly-(hexadecyl-cyanoacrylate), and poly[hexadecyl cyanoacrylate-co-methoxypoly(ethylene glycol) cyanoacrylate], respectively. ${ }^{15,16} \mathrm{Next}, 10 \mathrm{mg}$ of the copolymer was dissolved in $2 \mathrm{~mL}$ of acetone, and this solution was added dropwise to $4 \mathrm{~mL}$ of an $0.5 \%(\mathrm{w} / \mathrm{v})$ aqueous solution of Pluronic F68 under vigorous mechanical stirring. A milky suspension was observed almost immediately. The acetone was removed under reduced pressure and the nanoparticles were purified by ultracentrifugation $(150,000 \mathrm{~g}$ for one hour at $4{ }^{\circ} \mathrm{C}$ ) in order to eliminate the free polymer and the quasitotality of Pluronic F68. The supernatant was discarded and the pellet was resuspended in MilliQ water to yield the required concentration of nanoparticles. PACA and PEGPACA were characterized in terms of particle size and zeta potential by dynamic laser light scattering using a Nano ZS (Malvern, Worcestershire, UK) with a $173^{\circ}$ scattering angle at $25^{\circ} \mathrm{C}$, as previously reported. ${ }^{15,16}$

\section{HUVECs and RAW264.7 cell cultures}

HUVECs were cultured in endothelial cell growth medium-2 containing the EGM-2 SingleQuot kit supplement in a humidified chamber at $37^{\circ} \mathrm{C}$ with a $5 \% \mathrm{CO}_{2}$ and $95 \%$ air atmosphere. The cells were cultured in T75 flasks and 12-well tissue culture plates. For these studies, the cells were used for up to six passages, according to the manufacturer's instructions. The RAW264.7 murine monocytic macrophage cell line was grown in a plastic culture flask in Dulbecco's modified Eagle's medium (Gibco, Grand Island, NY, USA) supplemented with L-glutamine, $10 \%$ fetal bovine serum, and $1 \%$ penicillin/streptomycin under $5 \% \mathrm{CO}_{2}$ at $37^{\circ} \mathrm{C}$. After 4-5 days, the cells were scraped from the culture flask and centrifuged for 5 minutes at $125 \mathrm{~g}$. The medium was then removed and the cells were resuspended in fresh Dulbecco's modified Eagle's medium and cultured in 96-well tissue culture plates. ${ }^{17}$

\section{Treatment of cell lines with nanoparticles}

HUVECs and macrophages at $80 \%-90 \%$ confluence were treated for 24 hours with the different nanoparticles. Small aliquots of more highly concentrated nanoparticle solution were added to the culture medium in order to obtain the required concentrations at a final volume of $500 \mu \mathrm{L}$ or $100 \mu \mathrm{L}$ for HUVECs and macrophages, respectively. The liposomes were used at concentrations ranging from $6 \mu \mathrm{g} / \mathrm{mL}$ to $120 \mu \mathrm{g} / \mathrm{mL}$; solid lipid nanoparticles were used at concentrations ranging from $10 \mu \mathrm{g} / \mathrm{mL}$ to $1500 \mu \mathrm{g} / \mathrm{mL}$; and PACA were used at concentrations ranging from $0.64 \mu \mathrm{g} / \mathrm{mL}$ to $640 \mu \mathrm{g} / \mathrm{mL}$. As a negative control, cells were incubated in culture medium containing aliquots of phosphate-buffered saline or MilliQ water in the same amounts as those of the nanoparticles to which the cells were exposed. The HUVECs and macrophages were also treated with resveratrol $100 \mu \mathrm{M}(22.8 \mathrm{mg} / \mathrm{mL})$ and $1 \mu \mathrm{g} / \mathrm{mL}$ lipopolysaccharide from Escherichia coli, respectively, as positive controls for observation of production of nitric oxide. ${ }^{18,19}$ 


\section{Assessment of cell viability by MTT assay}

The cells were treated with the different doses of nanoparticles for 24 hours, and cell viability was then evaluated by MTT ([3-(4,5-dimetiltiazol-2-yl)-2,5-diphenyltetrazolium bromide]) assay. ${ }^{20}$ MTT was dissolved in phosphate-buffered saline $(0.5 \% \mathrm{w} / \mathrm{v})$, added to the cells, and incubated for 2 hours at $37^{\circ} \mathrm{C}$ in a humidified chamber. After incubation, ethanol was added to each well to dissolve the formazan crystals formed. Absorbance at $550 \mathrm{~nm}$ was measured using a microplate reader (Victor3 1420 Multilabel Counter, Perkin Elmer, Boston, MA, USA). Untreated cells were used as a negative control. Each sample was analyzed at least in triplicate. ${ }^{17}$

\section{Measurement of nitric oxide production after exposure to nanoparticles}

Production of nitric oxide by cells was measured in conditioned medium using the Griess method. ${ }^{21}$ The colorimetric Griess reaction for nitrite was used to determine the concentration of nitric oxide. Because nitric oxide present in biological fluids is recovered in nitrate form, the media were treated with nitrate reductase $(10 \mathrm{U} / \mathrm{mL})$ and nicotinamide adenine dinucleotide phosphate oxidase ( $5 \mathrm{mM}$ in Tris-Cl) for 3 hours at room temperature in order to reduce nitrate to nitrite. Finally, the samples were mixed with an equal volume of freshly prepared Griess reagent $(0.05 \% N$-[1-naphthyl] ethylenediamine dihydrochloride and $0.5 \%$ sulfanilamide in $2.5 \%$ orthophosphoric acid) for 20 minutes. Absorbance of each sample was measured at $540 \mathrm{~nm}$ using the microplate reader. Concentrations of nitric oxide in the samples were determined using a calibration curve generated with standard $\mathrm{NaNO}_{2}$ solutions $(0.1-100 \mu \mathrm{M})$.

\section{Detection of eNOS phosphorylation}

Total cell lysates were obtained by resuspending the cells in $100 \mu \mathrm{L}$ of lysis buffer (containing $2 \%$ sodium dodecyl sulfate, $50 \mathrm{mM}$ Tris- $\mathrm{HCl}$, $\mathrm{pH} 6.8,1 \mathrm{mM}$ complete protease inhibitor cocktail, and phosphatase inhibitors, ie, $2 \mathrm{mM}$ sodium orthovanadate, $1 \mathrm{mM}$ sodium fluoride, $1 \mathrm{mM}$ sodium pyrophosphate) and harvested by scraping with a rubber policeman spatula. An aliquot of the total cell lysate was analyzed for protein content using the bicinchoninic acid assay (Sigma-Aldrich). After boiling for 5 minutes at $100^{\circ} \mathrm{C}$, equal amounts of the samples (loaded with $15 \mu \mathrm{g}$ of proteins) were subjected to sodium dodecyl sulfate polyacrylamide gel electrophoresis using precast NuPAGE $4 \%-12 \%$ gel, and the proteins were transferred to a nitrocellulose membrane.
For detection of $\beta$-actin, the membrane was blocked for 30 minutes at $37^{\circ} \mathrm{C}$ in Tris-buffered saline buffer containing $0.1 \%$ Tween and $5 \%$ nonfat milk and incubated overnight at $4^{\circ} \mathrm{C}$ with anti- $\beta$-actin (1:1500). For eNOS and eNOS phosphorylation, the membrane was blocked for 30 minutes at $37^{\circ} \mathrm{C}$ in Tris-buffered saline buffer containing $0.1 \%$ Tween and $5 \%$ bovine serum albumin and then incubated overnight at $4{ }^{\circ} \mathrm{C}$ with anti-eNOS $(1: 1000)$ or anti-eNOS phosphorylation (1:1000). Immunoreactive proteins were revealed by enhanced chemiluminescence after incubation for 2 hours at room temperature with horseradish peroxidase-conjugated secondary antibodies. ${ }^{22}$ The intensity of the chemiluminescent spots was estimated semiquantitatively using Kodak Molecular Imaging software and expressed as the ratio between intensity of the spot of interest and intensity of the $\beta$-actin bands. ${ }^{23}$

\section{Analysis of apoptosis by caspase- 3 detection}

HUVECs were exposed to the experimental nanoparticles for 24 hours at concentrations that induced cell death. After exposure, total cell lysates were obtained and analyzed using sodium dodecyl sulfate polyacrylamide gel electrophoresis/ Western blotting as described above. For detection of caspase-3, the membrane was blocked for 30 minutes at $37^{\circ} \mathrm{C}$ in Tris-buffered saline buffer containing $0.1 \%$ Tween and 5\% nonfat milk and incubated overnight at $4{ }^{\circ} \mathrm{C}$ with anticaspase-3 antibody (1:1000). Immunoreactive proteins were revealed as above, and described by enhanced chemiluminescence. Untreated cells were used as a negative control.

\section{Measurements of free intracellular calcium}

The calcium ion fluorescence experiments were performed by culturing HUVECs in black, clear-bottomed 96-well plates (Greiner Bio-one, Solingen, Germany). Changes in intracellular free calcium levels were measured using Fluo4-AM fluorescent dye as an indicator. The cells were loaded with $5 \mu \mathrm{M}$ Fluo-4 AM dissolved in medium for 60 minutes at $37^{\circ} \mathrm{C}$, followed by an additional 30 minutes at room temperature to allow de-esterification of Fluo4-AM into its active dye form, Fluo-4. The cells were continuously exposed to $280 \mu \mathrm{M}$ of probenecid during cell loading and measurements to reduce or prevent dye leakage. The dye was excited at $488 \mathrm{~nm}$, and emissions at $520 \mathrm{~nm}$ were measured at $5 \mathrm{~Hz}$ using a plate reader. The results were expressed as changes in fluorescence intensity as a function of time. Different amounts of 
liposomes (from 30 to $120 \mu \mathrm{g} / \mathrm{mL}$ ) were applied as a bolus from a micropipette located in the vicinity of the well and the fluorescence changes were measured. Medium or phosphatebuffered saline and ATP $(100 \mu \mathrm{M})$ were used as the negative and positive control, respectively. ${ }^{24}$

\section{Statistical analysis}

All experiments were carried out at least in triplicate. The statistical analysis was performed using OriginPro8 (OriginLab Corporation, Northampton, MA, USA). The data were compared using the unpaired Student's $t$-test and expressed as the mean \pm standard error of the mean.

\section{Results}

\section{Characterization of nanoparticles}

The liposomes and PACA were characterized by dynamic laser light scattering, as described elsewhere. ${ }^{1,2}$ The plain liposomes had a mean diameter of $120 \pm 10 \mathrm{~nm}$ with a negative zeta potential of $-25.5 \pm 0.9 \mathrm{mV}$, that was slightly smaller in liposomes embedding anionic phospholipids (phosphatidic acid or cardiolipin). The particle size and zeta potential remained constant for up to 72 hours, within the experimental error. The PACA had a mean diameter of $160 \pm 3 \mathrm{~nm}$ and a negative zeta potential of $-24 \pm 4 \mathrm{mV}$, that was decreased slightly for PEG-PACA. These data are very similar to those already reported. ${ }^{1,2}$ The solid lipid nanoparticles had a mean diameter of $250 \pm 20 \mathrm{~nm}$ and a negative zeta potential of $-41 \pm 1.60 \mathrm{mV}$, that decreased slightly after functionalization with phosphatidic acid $(-44 \pm 1.78 \mathrm{mV})$, and were stable for the 72 hours of observation, within the experimental error, as measured by dynamic laser light scattering.

\section{Cell viability after exposure to nanoparticles}

The viability of HUVECs and RAW264.7 cells in response to exposure to the different doses of nanoparticles was assessed. Treatment of macrophages with plain liposomes and PA-LIP significantly decreased cell viability in a dosedependent manner (from $6 \mu \mathrm{g} / \mathrm{mL}$ to $120 \mu \mathrm{g} / \mathrm{mL}$ of total lipids), whereas treatment with CL-LIP decreased cell viability by about $30 \%$ at all concentrations tested (Figure 1). None of the liposomes tested induced a reduction in the viability of HUVECs (data not shown).

When using solid lipid nanoparticles or PA-SLN, a dose-dependent decrease in cell viability was found for both HUVECs (Figure 2A) and macrophages (Figure 2B). In general, macrophages showed much higher cellular suffering ( $\mathrm{IC}_{50}$ solid lipid nanoparticles, $100 \pm 10 \mu \mathrm{g} / \mathrm{mL}$; IC ${ }_{50}$ PA-SLN, $110 \pm 9 \mu \mathrm{g} / \mathrm{mL})$ than HUVECs $\left(\mathrm{IC}_{50}\right.$ solid lipid nanoparticles, $7000 \pm 510 \mu \mathrm{g} / \mathrm{mL} ; \mathrm{IC}_{50}$ PA-SLN, $3500 \pm 210 \mu \mathrm{g} / \mathrm{mL}$ ) after exposure to solid lipid nanoparticles or PA-SLN. The viability of HUVECs was significantly reduced after exposure to PACA $\left(\mathrm{IC}_{50}, 7050 \pm 450 \mu \mathrm{g} / \mathrm{mL}\right)$ or PEG-PACA $\left(\mathrm{IC}_{50}\right.$, $6180 \pm 290 \mu \mathrm{g} / \mathrm{mL}$ ), starting from $640 \mu \mathrm{g} / \mathrm{mL}$ for PACA and $64 \mu \mathrm{g} / \mathrm{mL}$ for PEG-PACA (Figure 3A). A dose-dependent decrease in viability of the macrophages was detected at $64 \mu \mathrm{g} / \mathrm{mL}$ for PACA $\left(\mathrm{IC}_{50}, 110 \pm 9 \mu \mathrm{g} / \mathrm{mL}\right)$ and $6.4 \mu \mathrm{g} / \mathrm{mL}$ for PEG-PACA $\left(\mathrm{IC}_{50}, 95 \pm 11 \mu \mathrm{g} / \mathrm{mL}\right.$, Figure $\left.3 \mathrm{~B}\right)$.

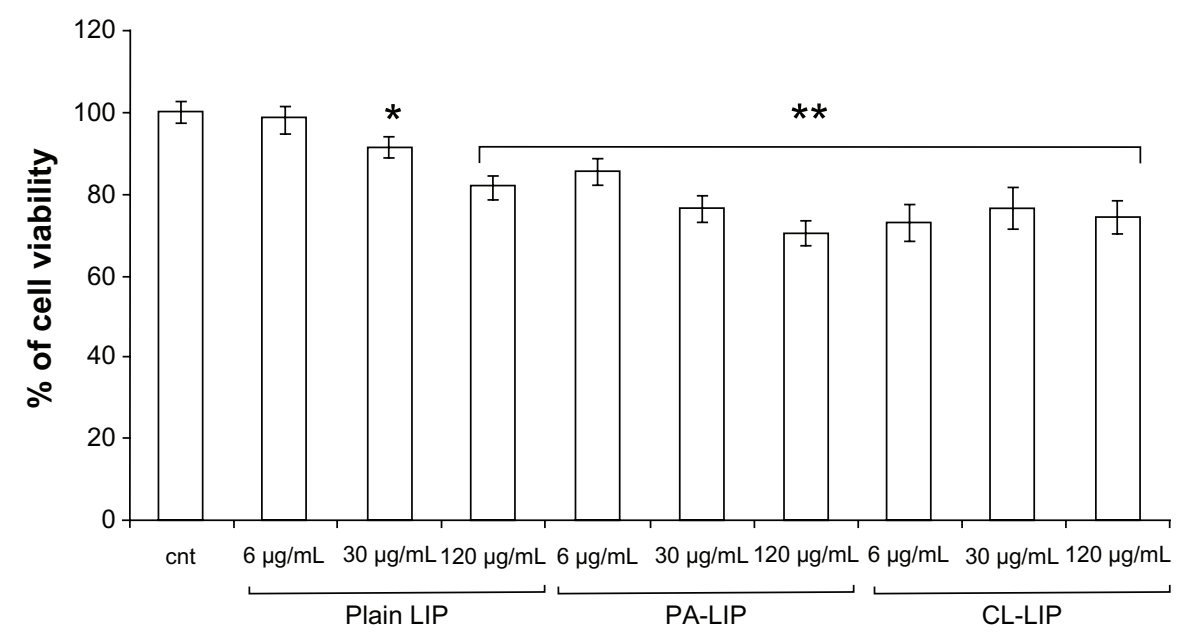

Figure I Viability of RAW264.7 macrophages after treatment with liposomes.

Notes: The cells were incubated with different concentrations $(6-120 \mu \mathrm{g} / \mathrm{mL})$ of plain LIP, PA-LIP or CLCL, CL-LIP for 24 hours and viability was determined by MTT assay. The results are reported as the percentage of cell viability using untreated cells as a control. The data are reported as the mean \pm standard error of the mean of triplicate experiments. The results were compared using the Student's $t$-test. $* P<0.05 ; * * P<0.01$.

Abbreviations: LIP, liposomes; CL, cardiolipin; PA, phosphatidic acid. 


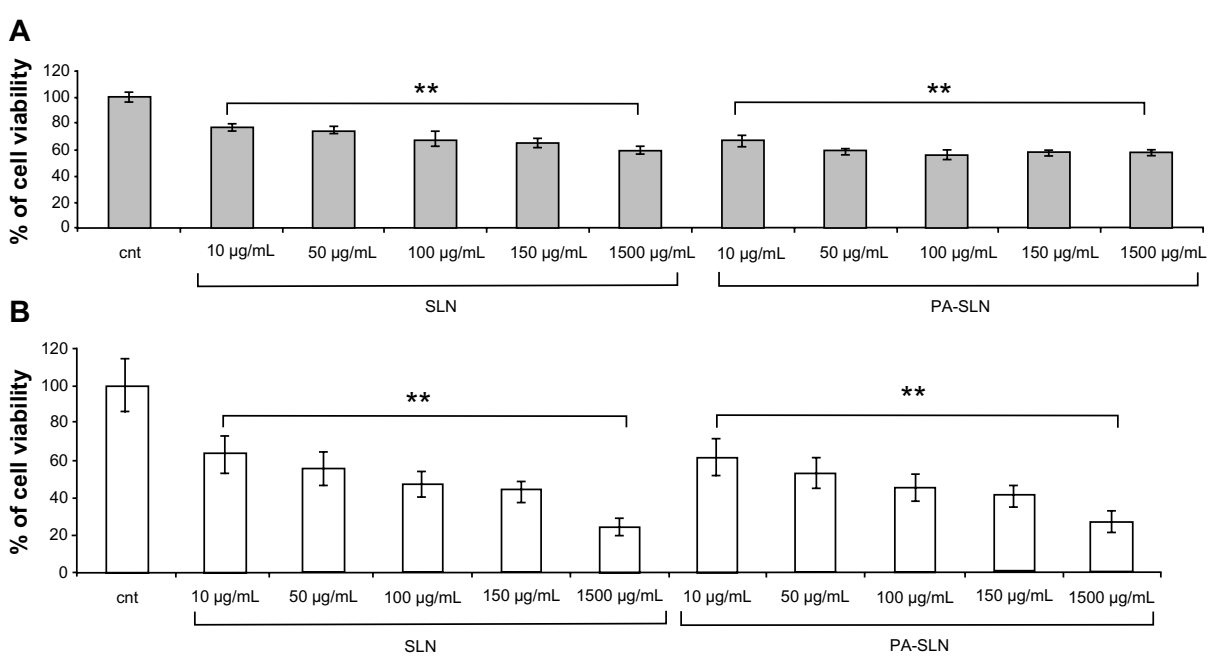

Figure 2 Viability of human umbilical vein endothelial cells and RAW264.7 macrophages after treatment with solid lipid nanoparticles. (A) Human umbilical vein endothelial cells and (B) RAW264.7 macrophages were incubated with different concentrations ( $10-1500 \mu \mathrm{g} / \mathrm{mL})$ of solid lipid nanoparticles or PA-SLN for 24 hours and viability was determined by MTT assay.

Notes: The results are reported as the percentage of cell viability using untreated cells as a control. The data are reported as the mean \pm standard error of the mean of triplicate experiments. The results were compared using the Student's $t$-test. $* * p<0.0$ I.

Abbreviations: cnt, untreated cells; SLN, solid lipid nanoparticles; PA, phosphatidic acid.

\section{Nitric oxide production by cells exposed to nanoparticles}

Nitric oxide levels in HUVECs and RAW264.7 cells were measured after exposure to the different doses of nanoparticles. PA-LIP and CL-LIP at the highest dose $(120 \mu \mathrm{g} / \mathrm{mL}$ of total lipids) significantly increased nitric oxide production in HUVECs (by approximately $21 \%$ and $27 \%$, respectively) compared with nonexposed cells (Figure 4). The macrophages did not show an increase in nitric oxide production (data not shown).

Increased nitric oxide production was detected when HUVECs were exposed to solid lipid nanoparticles and PA-SLN, starting from $100 \mu \mathrm{g} / \mathrm{mL}$ for solid lipid nanoparticles and from $150 \mu \mathrm{g} / \mathrm{mL}$ for PA-SLN (Figure $5 \mathrm{~A}$ ). In macrophages,
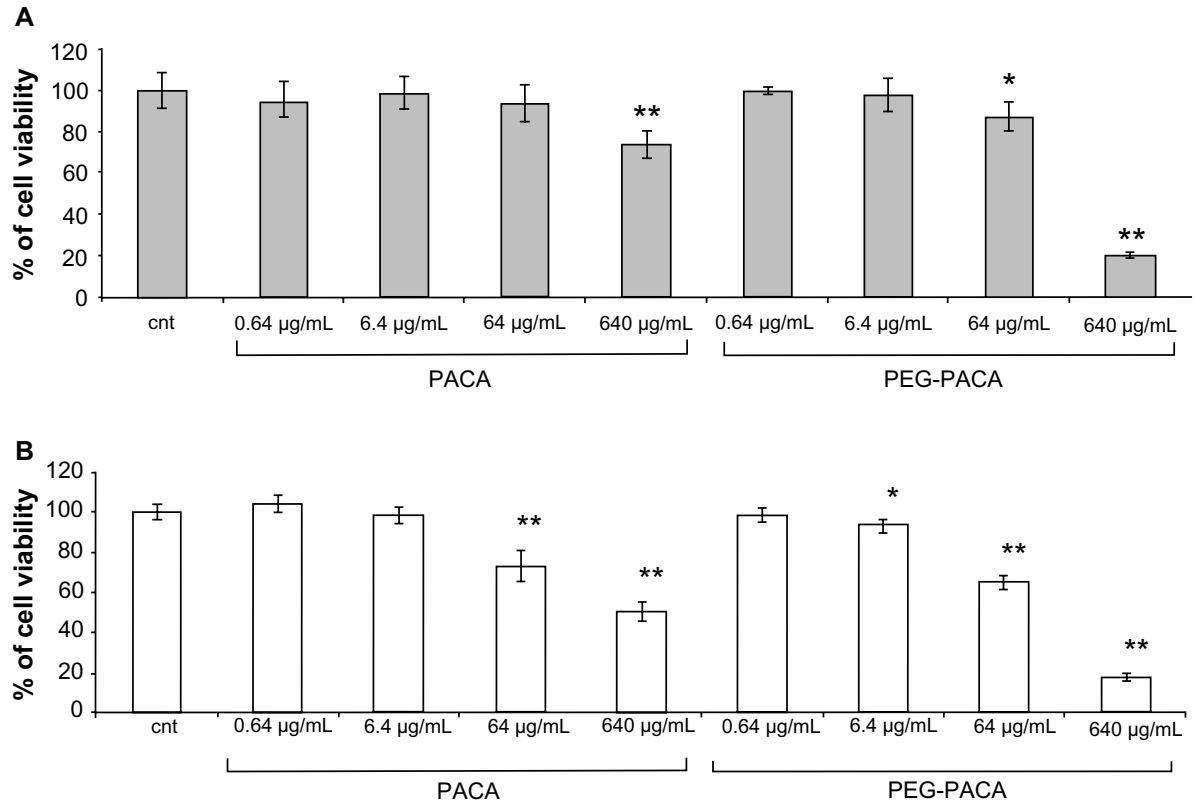

Figure 3 Viability of human umbilical vein endothelial cells and RAW264.7 macrophages after treatment with PACA. (A) Human umbilical vein endothelial cells and (B) RAW264.7 macrophages were incubated with different concentrations $(0.64-640 \mu \mathrm{g} / \mathrm{mL})$ of PACA or PEG-PACA for 24 hours and viability was determined by MTT assay. Notes: The results are reported as the percentage of cell viability using untreated cells as a control. The data are reported as the mean \pm standard error of the mean of triplicate experiments. The results were compared using the Student's $t$-test. $* P<0.05$; $* * P<0.01$.

Abbreviations: cnt, untreated control cells; PEG-PACA, PEGylated poly(alkyl cyanoacrylate) nanoparticles. 


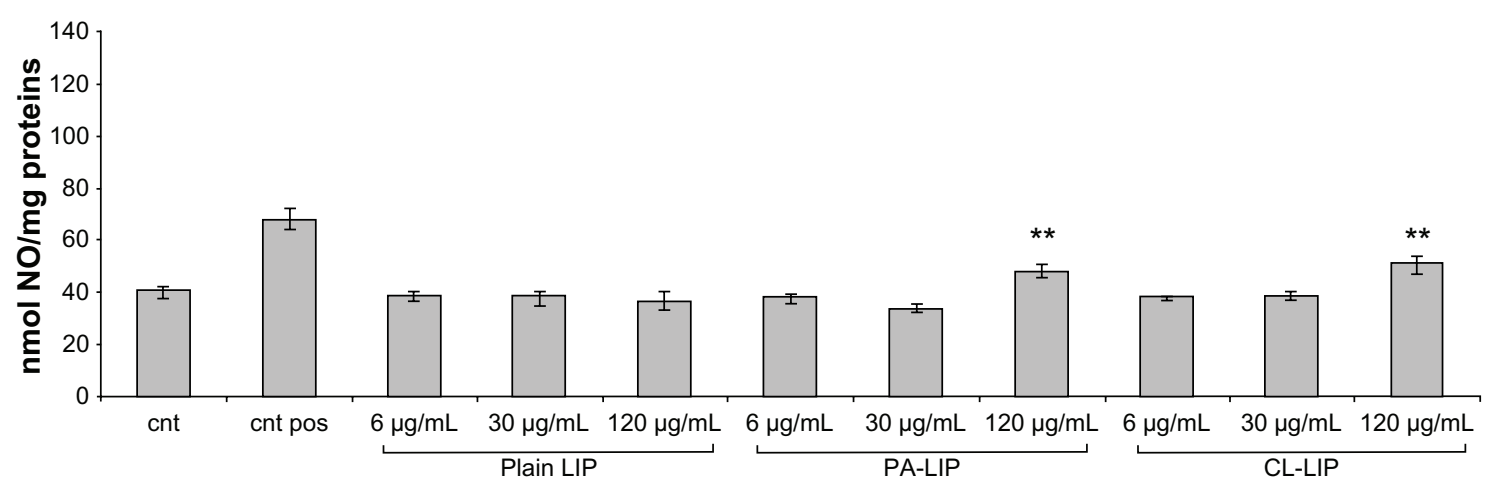

Figure 4 Production of nitric oxide by human umbilical vein endothelial cells after treatment with liposomes.

Notes: Cells were incubated with different concentrations $(6-120 \mu \mathrm{g} / \mathrm{mL})$ of plain LIP, PA-LIP, or CL-LIP for 24 hours, and production of nitric oxide was measured in conditioned medium using the Griess method. Cells treated with resveratrol were used as a positive control; untreated cells were used as a negative control. The data are reported as the mean \pm standard error of the mean of triplicate experiments. The results were compared using the Student's $t$-test. $* * P<0.01$.

Abbreviations: LIP, liposomes; CL, cardiolipin; PA, phosphatidic acid; pos, positive control; cnt, untreated cells.

a significant increase in nitric oxide production compared with untreated cells (from $+57 \%$ to $+71 \%$ ), was detected only at the highest nanoparticle dose $(1500 \mu \mathrm{g} / \mathrm{mL}$, Figure $5 \mathrm{~B})$.

In HUVECs, PACA and PEG-PACA induced a significant increase in nitric oxide production compared with untreated cells, but only at the highest doses $(640 \mu \mathrm{g} / \mathrm{mL}$ and $64 \mu \mathrm{g} / \mathrm{mL}$, respectively) (Figure 6A). Increased nitric oxide production by macrophages was detected starting from lower concentrations of nanoparticles $(64 \mu \mathrm{g} / \mathrm{mL}$, Figure $6 \mathrm{~B})$. Of note is that all nanoparticle treatments, except for solid lipid nanoparticles at the highest dose $(1500 \mu \mathrm{g} / \mathrm{mL})$, induced production of nitric oxide at a significantly lower level than the positive control.

\section{Levels of eNOS phosphorylation after exposure to nanoparticles}

The degree of phosphorylation of eNOS was also assessed, given that production of nitric oxide is correlated with phosphorylation of this protein. Levels of eNOS phosphorylation were measured in HUVECs using the nanoparticle concentration at which nitric oxide production was detectable (PA-LIP or CL-LIP $120 \mu \mathrm{g} / \mathrm{mL}$ ). Phosphorylation of eNOS was increased by about $50 \%$ in cells exposed to PA-LIP or CL-LIP compared with nonexposed cells, whereas cells exposed to plain liposomes did not show any change in phosphorylation of eNOS (Figure 7).

\section{Detection of caspase-3 cleavage after exposure to nanoparticles}

The caspase- 3 analysis, which excluded apoptosis-mediated cell death, was carried out in HUVECs after exposure to the nanoparticles. No cleavage of caspase- 3 was detected after treatment with any of the nanoparticles tested (data not shown).

\section{Free intracellular calcium ion levels}

Because production of nitric oxide and intracellular $\mathrm{Ca}^{2+}$ levels are biochemically related, the amount of free $\mathrm{Ca}^{2+}$ were measured in HUVECs treated with PA-LIP or CL-LIP $120 \mu \mathrm{g} / \mathrm{mL}$, the concentration at which nitric oxide production was detectable.

The Fluo-4 fluorescence changes induced by exposure of HUVECs to liposomes are shown in Figure 8, and demonstrate that when the cells were treated with plain liposomes or vehicle (phosphate-buffered saline), no significant change was observed in the fluorescence signal, indicating no change in the intracellular $\mathrm{Ca}^{2+}$ concentration (Figure 8A). However, when the cells were treated with a bolus of PA-LIP or CL-LIP at a total lipid concentration of $120 \mu \mathrm{g} / \mathrm{mL}$, they showed an initial increase and a subsequent sustained fluorescence signal corresponding to an increase in free intracellular free calcium (Figure 8B and C, respectively). HUVECs treated with PA-LIP (Figure 8B) showed an increase in fluorescence of about $6.5 \%$ that was maintained throughout the measurements, and cells treated with CL-LIP (Figure 8C) showed a fluorescence increase of about $8.5 \%$. Fluo-4-loaded HUVECs showed a strong increase in intracellular fluorescence after treatment with $100 \mu \mathrm{M}$ ATP, compared with HUVECs loaded with Fluo-4 (Figure 8D).

\section{Discussion}

Engineered nanomaterials are now being shown to be interesting biomedical tools, and are potentially able to resolve concerns about efficacy, cellular uptake, and specific transport of drugs and/or imaging agents to target organs, in particular in the case of neurodegenerative diseases like Alzheimer's Disease. ${ }^{25,26}$ 

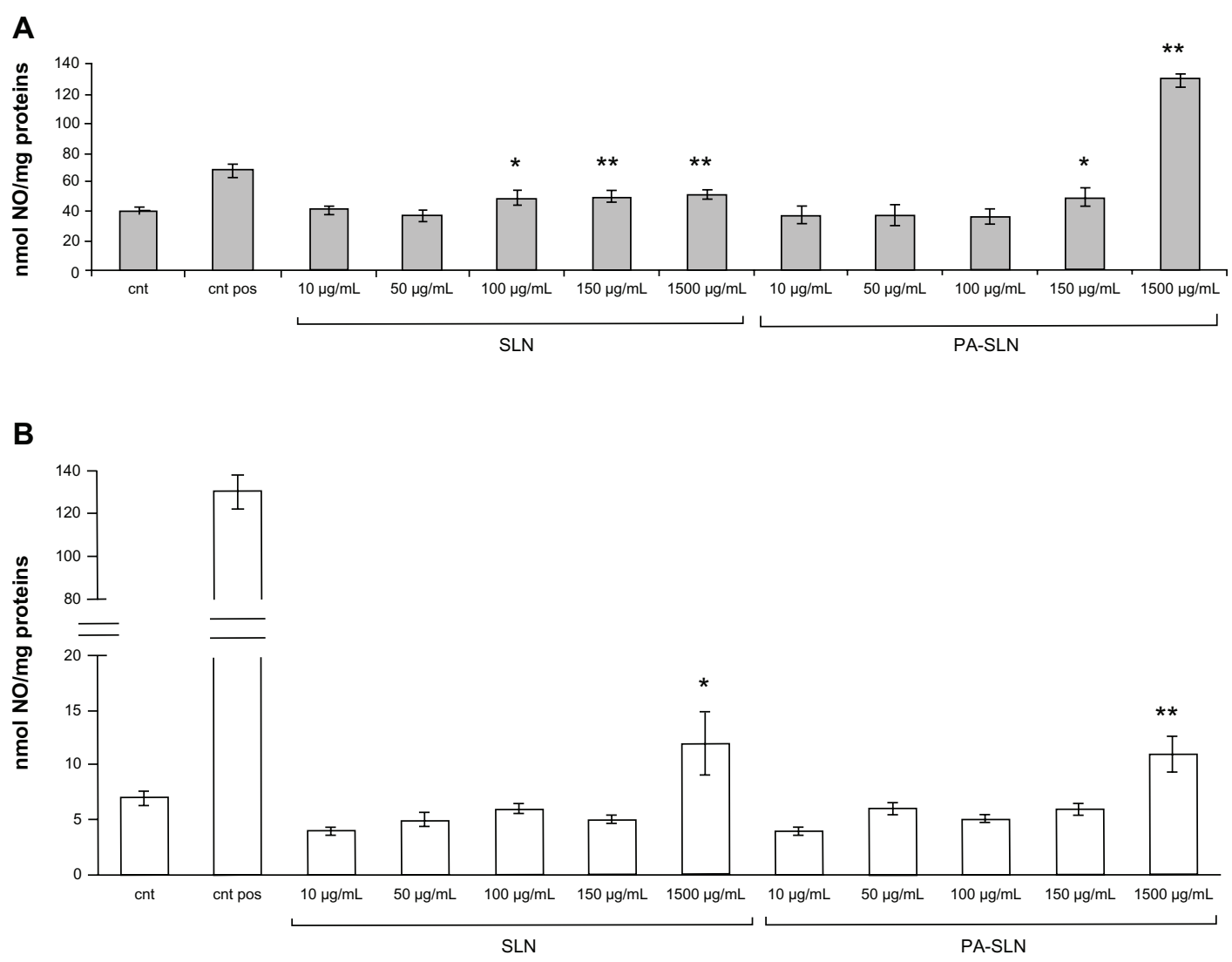

Figure 5 Production of nitric oxide by human umbilical vein endothelial cells and RAW264.7 macrophages after treatment with solid lipid nanoparticles. (A) Human umbilical vein endothelial cells and (B) RAW264.7 macrophages were incubated with different concentrations (I0-1500 $\mu \mathrm{g} / \mathrm{mL}$ ) of solid lipid nanoparticles or PA-SLN for 24 hours, and production of nitric oxide was measured in conditioned medium using the Griess method.

Notes: Human umbilical vein endothelial cells treated with resveratrol and RAW264.7 macrophages treated with lipopolysaccharide were used as a positive control; untreated cells were used as a negative control. The data are reported as the mean \pm standard error of the mean of triplicate experiments. The results were compared using the Student's t-test. $* P<0.05 ; * * P<0.01$.

Abbreviations: cnt pos, positive control; cnt, untreated cells; SLN, solid lipid nanoparticles; PA, phosphatidic acid.

In a series of investigations carried out within the framework of the FP7 EU project known as NAD (Nanoparticles for therapy and diagnosis of Alzheimer's Disease), we designed a series of lipid and polymer-based nanoparticles able to bind with high affinity to aggregate forms of $\beta$-amyloid peptide ${ }^{1,2}$ and to reduce cytotoxicity ${ }^{4}$ or aggregation of the peptide in vitro. ${ }^{2,27}$

In order to evaluate cytotoxicity after administration in vivo, we measured nitric oxide production by cultured primary HUVECs and mouse macrophages (RAW264.7 cells) after exposure to these nanoparticles. Certain types of nanoparticles, particularly those composed of silica or metal, have been shown to affect the endothelial system, retarding cell growth, modifying endothelium-dependent vasodilation, and enhancing secretion of proinflammatory cytokines, apoptosis, and/or endothelial cell adhesion (see Supplementary Table). ${ }^{28-30}$

In this study, liposomes functionalized with phosphatidic acid or cardiolipin as $\beta$-amyloid ligands ${ }^{31}$ were tested at concentrations commonly used in vivo for delivery of therapeutics. ${ }^{32,33}$ Exposure to liposomes of any type and concentration did not have toxic effects on HUVECs in terms of cell viability, but an increase in nitric oxide production was detected at the highest dose of PA-LIP or CL-LIP. It is known that production of nitric oxide by the eNOS protein requires its enzymatic dissociation from the caveolae and successive phosphorylation..$^{9}$ This dissociation can occur as a result of an increase in intracellular levels of free $\mathrm{Ca}^{2+} .7$ Our results show that levels of intracellular $\mathrm{Ca}^{2+}$ and of eNOS phosphorylation were increased after exposure of HUVECs to PA-LIP or CL-LIP, so it is likely that these nanoparticles could be responsible for production of nitric oxide by activating the intracellular calcium-eNOS phosphorylation cascade. ${ }^{34}$

RAW264.7 macrophages exposed to any type of liposome showed a mild dose-dependent decrease in viability when compared with nonexposed cells, along with detectable changes in cell morphology. No changes in nitric oxide production were detected on exposure to any concentration 


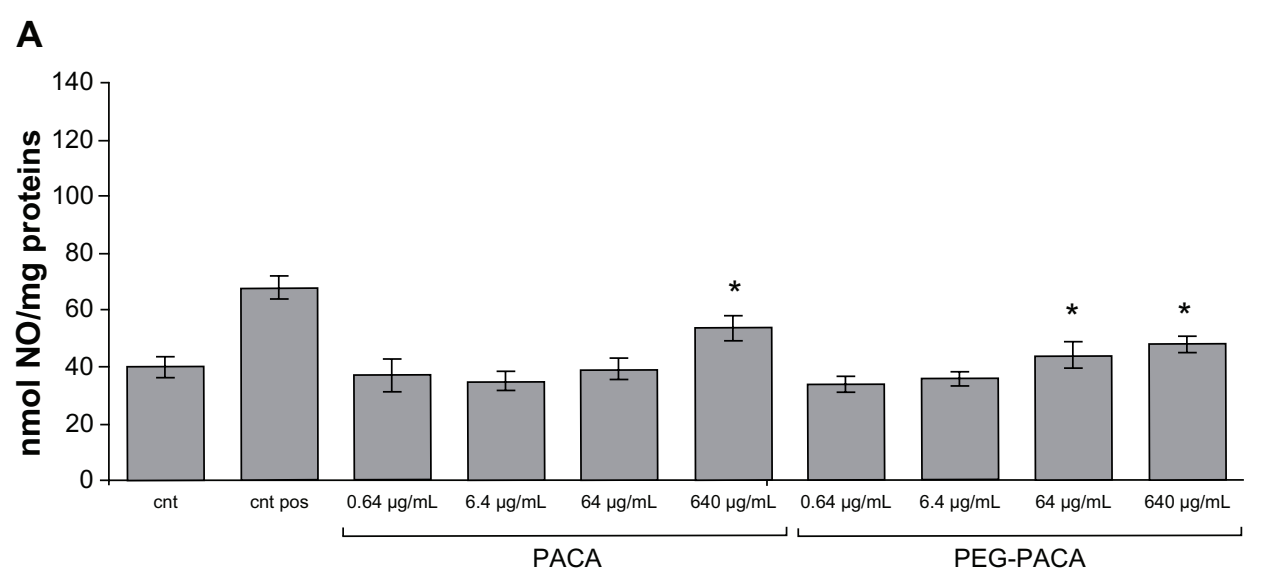

B

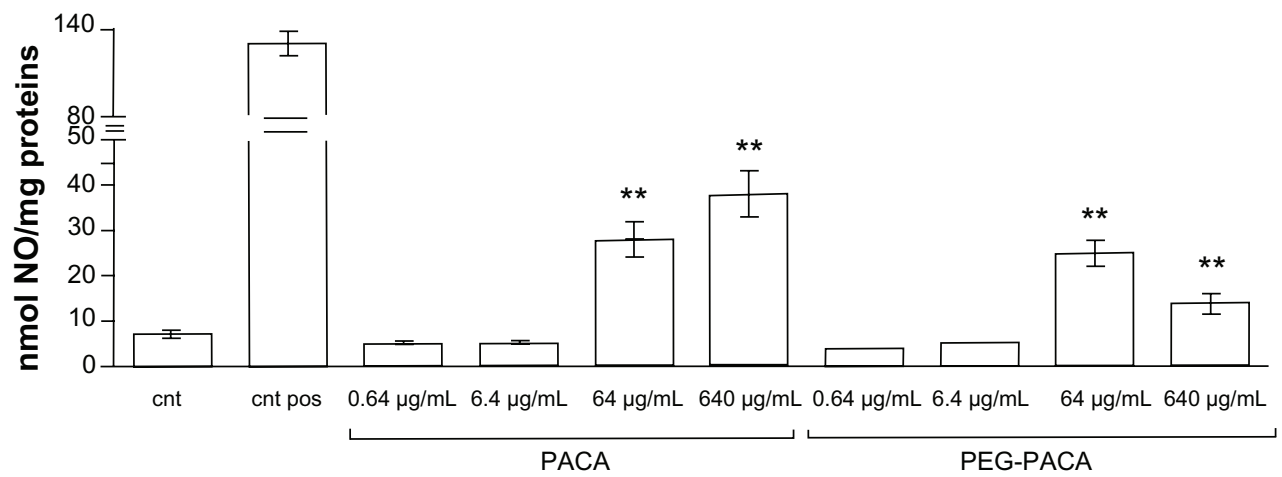

Figure 6 Production of nitric oxide by human umbilical vein endothelial cells and RAW264.7 macrophages after treatment with PACA. (A) Human umbilical vein endothelial cells and (B) RAW264.7 macrophages were incubated with different concentrations $(0.64-640 \mu \mathrm{g} / \mathrm{mL})$ of PACA or PEG-PACA for 24 hours, and production of nitric oxide was measured in conditioned medium using the Griess method.

Notes: Human umbilical vein endothelial cells treated with resveratrol and RAW264.7 macrophages treated with lipopolysaccharide were used as a positive control; untreated cells were used as a negative control. The data are reported as the mean \pm standard error of the mean of triplicate experiments. The results were compared using the Student's $t$-test. $* P<0.05$; $* * P<0.01$.

Abbreviations: cnt pos, positive control; cnt, untreated cells; PEG, poly(ethylene glycol); PACA, poly(alkyl cyanoacrylate).
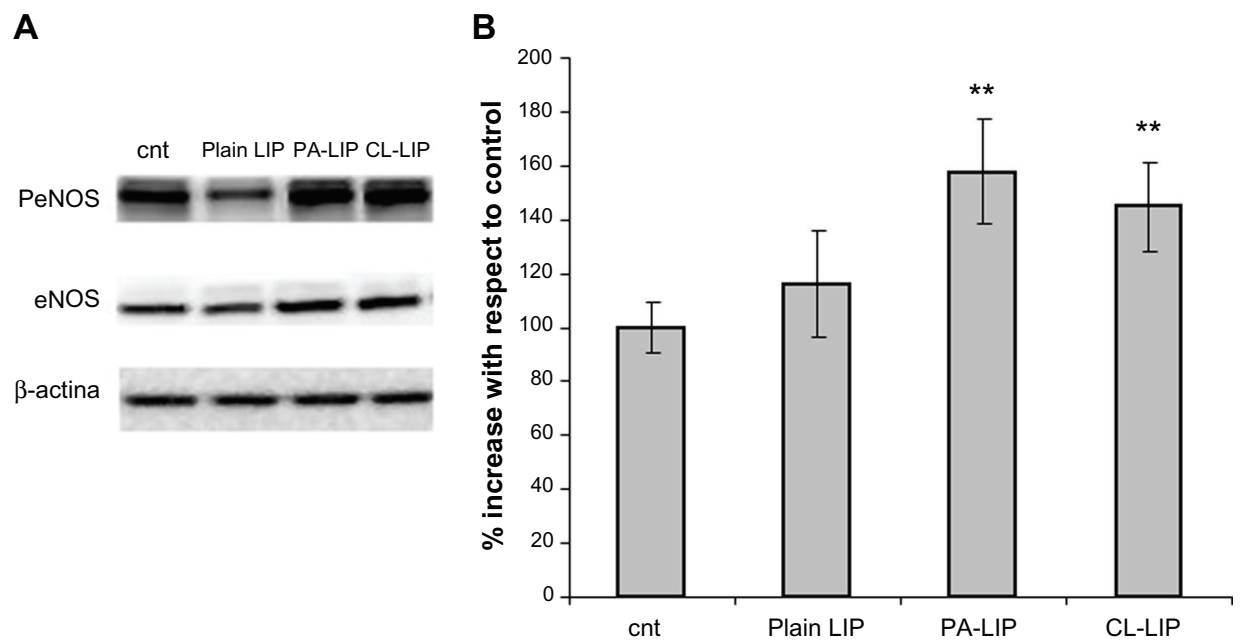

Figure 7 Levels of eNOS phosphorylation in human umbilical vein endothelial cells after treatment with liposomes. Cells were treated with I20 $\mu g / \mathrm{mL}$ of plain LIP, PA-LIP, or CL-LIP for 24 hours, and total cell lysates were submitted for sodium dodecyl sulfate polyacrylamide gel electrophoresis and Western blot analysis. (A) eNOS phosphorylation and eNOS were detected by immunoblotting, followed by enhanced chemiluminescence detection. Immunodetection of $\beta$-actin was used to confirm equal protein loading in the different lanes. (B) The spot intensity was estimated semiquantitatively and expressed as the ratio between intensity of the spot of interest and intensity of the $\beta$-actin bands.

Notes: The data are shown as the mean \pm standard error of the mean of three separate experiments performed in triplicate. The results were compared using the Student's $t$-test. **P $<0.01$.

Abbreviations: eNOS, endothelial nitric oxide synthase; cnt, untreated cells; LIP, liposomes; CL, cardiolipin; PA, phosphatidic acid. 
A

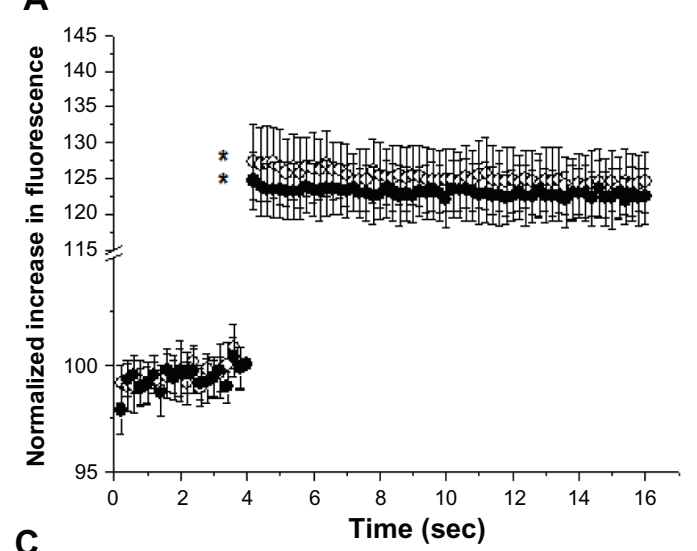

C

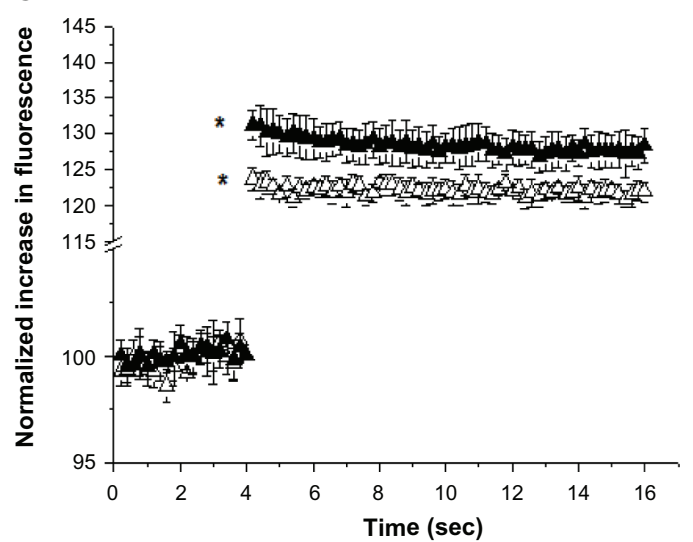

B
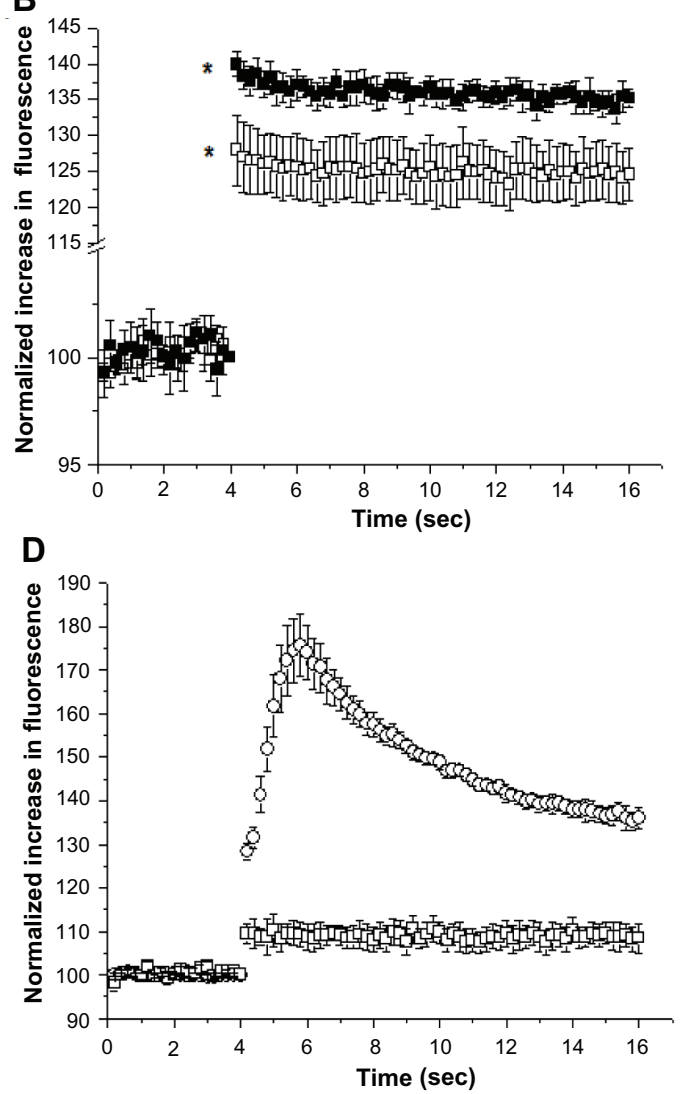

Figure 8 Levels of free $\mathrm{Ca}^{2+}$ in human umbilical vein endothelial cells after treatment with liposomes. Human umbilical vein endothelial cells were loaded with Fluo-4 followed by treatment with (A) plain liposomes, (B) PA-LIP, or (C) CL-LIP at concentrations of $30 \mu \mathrm{g} / \mathrm{mL}$ (empty symbols) or I20 $\mu \mathrm{g} / \mathrm{mL}$ (full symbols). Shown are averaged traces of Fluo-4 normalized fluorescence with respect to the baseline obtained from three similarly performed experiments each done in quadruplicate. (D) Changes in intracellular fluorescence on exposure of $100 \mu$ M ATP in Fluo-4 loaded (empty circles) or nonloaded (empty squares) human umbilical vein endothelial cells.

Notes: The results were compared using the Student's $t$-test. $* P<0.05$.

Abbreviations: LIP, liposomes; CL, cardiolipin; PA, phosphatidic acid.

of liposomes. These data suggest that liposomes cause mild metabolic stress in the cell, which is probably not sufficient to trigger an inflammatory response. Previously, Afergan et al and Cohen-Sela et al reported that RAW264.7 cells exposed to nanoparticles, including liposomes, were transiently inactivated, thereby compromising the function of cultured macrophages and leading to a diminished inflammatory response. ${ }^{35,36}$ Overall, our results suggest that PA-LIP and CL-LIP could potentially be used in vivo without triggering a negative response in endothelial cells or macrophages, but this needs further confirmation.

Exposure to solid lipid nanoparticles or PA-SLN at the range of concentrations previously used in vivo ${ }^{37,38}$ resulted in decreased viability of HUVECs, which was not mediated by apoptosis, and increased production of nitric oxide only at the highest doses. Further, excessive production of nitric oxide and distress was seen in the macrophages after exposure to the solid lipid nanoparticles. These effects may have been due to the type of lipid matrix and/ or surfactant used for preparation of solid lipid nanoparticles, as already discussed in the literature. ${ }^{39,40}$ However, solid lipid nanoparticles with a lipid matrix and surfactant similar to those used in the present study but of a different size have been found to have no toxic effects on other cell types in vitro. ${ }^{41}$

Overall, these results suggest that the chemical design of solid lipid nanoparticles plays an important role in determining their biocompatibility, and that the lipid matrix and size, in particular, should be chosen carefully. Further studies are needed to investigate the biocompatibility of solid lipid nanoparticles and the influence of chemical formulation on their safety and efficacy.

Finally, we assessed the effect of PACA nanoparticles, whether PEGylated or not, on production of nitric oxide and cell viability, and found a decrease in viability (not apoptosis-mediated) only at the highest concentrations tested 
and for both cell lines used. Further, excessive production of nitric oxide was detected at the highest nanoparticle doses, particularly for macrophages. These nanoparticles may cause production of even more nitric oxide than that seen in this study because of underestimation of their effect on cell death. It is important to highlight that, unlike in our study, the clinical application of these nanoparticles for biomedical purposes in the past has used doses which were too low to affect production of nitric oxide or cell viability. ${ }^{42}$ Moreover, given that more prolonged treatment would be required in the clinical setting than that used in this study, these experiments will now be carried out in vivo with longer incubation times.

\section{Conclusion}

The nanoparticles tested in this study, in particular liposomes and PACA nanoparticles, are potentially promising for the treatment of Alzheimer's disease. At the concentrations commonly used in vivo, they do not affect nitric oxide production in vitro and are not toxic to the types of cell present in blood. Moreover, the results of this study highlight the importance of testing nitric oxide production in vitro in order to establish the therapeutic dose range for nanoparticles intended for medical use.

\section{Acknowledgments}

This research received funding from the European Community's Seventh Framework Programme (FP7/2007-2013) under grant agreement 212043 (to NAD). We are grateful to Francesco Mantegazza for his kind assistance with calculation of the $\mathrm{IC}_{50}$ values.

\section{Disclosure}

The authors report no conflicts of interest in this work.

\section{References}

1. Gobbi M, Re F, Canovi M, et al. Lipid-based nanoparticles with high binding affinity for amyloid-beta1-42 peptide. Biomaterials. 2010;31(25):6519-6529.

2. Brambilla D, Verpillot R, Le Droumaguet B, et al. PEGylated nanoparticles bind to and alter amyloid-beta peptide conformation: towards engineering of functional nanomedicines for Alzheimer's disease. ACS Nano. 2012;6(7):5897-5908.

3. Canovi M, Markoutsa E, Lazar AN, et al. The binding affinity of anti-A $\beta 1-42$ MAb-decorated nanoliposomes to A $\beta 1-42$ peptides in vitro and to amyloid deposits in post-mortem tissue. Biomaterials. 2011;32(23):5489-5497.

4. Bereczki E, Re F, Masserini ME, et al. Liposomes functionalized with acidic lipids rescue $A \beta$-induced toxicity in murine neuroblastoma cells. Nanomedicine. 2011;7(5):560-571.

5. Vauthier C, Dubernet C, Fattal E, et al. Poly(alkylcyanoacrylates) as biodegradable materials for biomedical applications. Adv Drug Deliv Rev. 2003;55(4):519-548.
6. Lovren F, Pan Y, Shukla PC, et al. Visfatin activates eNOS via Akt and MAP kinases and improves endothelial cell function and angiogenesis in vitro and in vivo: translational implications for atherosclerosis. Am J Physiol Endocrinol Metab. 2009;296(6):E1440-E1449.

7. Fulton D, Gratton JP, Sessa WC. Post-translational control of endothelial nitric oxide synthase: why isn't calcium/calmodulin enough? J Pharmacol Exp Ther. 2001;299(3):818-824.

8. Fulton D, Gratton JP, McCabe TJ, et al. Regulation of endotheliumderived nitric oxide production by the protein kinase Akt. Nature. 1999; 399(6736):597-601.

9. Gratton JP, Fontana J, O'Connor DS, et al. Reconstitution of an endothelial nitric-oxide synthase (eNOS), hsp90, and caveolin-1 complex in vitro. Evidence that hsp90 facilitates calmodulin stimulated displacement of eNOS from caveolin-1. J Biol Chem. 2000;275(29): 22268-22272.

10. Bucci M, Gratton JP, Rudic RD, et al. In vivo delivery of the caveolin-1 scaffolding domain inhibits nitric oxide synthesis and reduces inflammation. Nat Med. 2000;6(12):1362-1367.

11. Dobrovolskaia MA, Aggarwal P, Hall JB, et al. Preclinical studies to understand nanoparticle interaction with the immune system and its potential effects on nanoparticle biodistribution. Mol Pharm. 2008;5(4): 487-495.

12. Walkey CD, Olsen JB, Guo H, et al. Nanoparticle size and surface chemistry determine serum protein adsorption and macrophage uptake. J Am Chem Soc. 2012;134(4):2139-2147.

13. Boscá L, Zeini M, Través PG, Hortelano S. Nitric oxide and cell viability in inflammatory cells: a role for $\mathrm{NO}$ in macrophage function and fate. Toxicology. 2005;208(2):249-258.

14. Ahlin P, Kristl J, Smid-Korbar J. Optimization of procedure parameters and physical stability of solid lipid nanoparticles in dispersions. Acta Pharm. 1998;48:257-267.

15. Brambilla D, Nicolas J, Le Droumaguet B, et al. Design of fluorescently tagged poly(alkyl cyanoacrylate) nanoparticles for human brain endothelial cell imaging. Chem Commun (Camb). 2010;46(15):2602-2604.

16. Le Droumaguet B, Nicolas J, Brambilla D, et al. Versatile and efficient targeting using a single nanoparticulate platform: application to cancer and Alzheimer's disease. ACS Nano. 2012;6(7):5866-5879.

17. Conforti F, Marrelli M, Menichini F, et al. Chemical composition and protective effect of oregano (Origanum heracleoticum L) ethanolic extract on oxidative damage and on inhibition of NO in LPS-stimulated RAW264.7 macrophages. $J$ Enzyme Inhib Med Chem. 2011;26(3): 404-411.

18. Wallerath T, Deckert G, Ternes T, et al. Resveratrol, a polyphenolic phytoalexin present in red wine, enhances expression and activity of endothelial nitric oxide synthase. Circulation. 2002;106(13): 1652-1658.

19. Hu W, Yang X, Zhe C, et al. Puerarin inhibits iNOS, COX-2 and CRP expression via suppression of NF- $\mathrm{KB}$ activation in LPS-induced RAW264.7 macrophage cells. Pharmacol Rep. 2011;63(3):781-789.

20. Re F, Cambianica I, Zona C, et al. Functionalization of liposomes with ApoE-derived peptides at different density affects cellular uptake and drug transport across a blood-brain barrier model. Nanomedicine. 2011;7:551-559.

21. Hevel JM, Marletta MA. Nitric-oxide synthase assays. Methods Enzymol. 1994;233:250-258.

22. Re F, Sesana S, Barbiroli A, et al. Prion protein structure is affected by $\mathrm{pH}$-dependent interaction with membranes: a study in a model system. FEBS Lett. 2008;582(2):215-220.

23. Bulbarelli A, Lonati E, Brambilla A, et al. A $\beta 42$ production in brain capillary endothelial cells after oxygen and glucose deprivation. $\mathrm{Mol}$ Cell Neurosci. 2012;49(4):415-422.

24. Gee KR, Brown KA, Chen WN, et al. Chemical and physiological characterization of fluo-4 Ca2+-indicator dyes. Cell Calcium. 2000;27(2): 97-106.

25. Brambilla D, Le Droumaguet B, Nicolas J, et al. Nanotechnologies for Alzheimer's disease: diagnosis, therapy, and safety issues. Nanomedicine. 2011;7(5):521-540. 
26. Re F, Gregori M, Masserini M. Nanotechnology for neurodegenerative disorders. Nanomedicine. 2012;8 Suppl 1:S51-S58.

27. Taylor M, Moore S, Mourtas S, et al. Effect of curcumin-associated and lipid ligand-functionalized nanoliposomes on aggregation of the Alzheimer's A $\beta$ peptide. Nanomedicine. 2011;7(5):541-550.

28. Zhu MT, Wang B, Wang Y, et al. Endothelial dysfunction and inflammation induced by iron oxide nanoparticle exposure: risk factors for early atherosclerosis. Toxicol Lett. 2011;203(2):162-171.

29. Napierska D, Quarck R, Thomassen LC, et al. Amorphous silica nanoparticles promote monocyte adhesion to human endothelial cells: size-dependent effect. Small. 2013;9(3):430-438.

30. Lacroix G, Dekali S, Divetain A, et al. Cell cooperation and role of the P2X7 receptor in pulmonary inflammation induced by nanoparticles. Nanotoxicology. 2012. Epub ahead of print.

31. Re F, Airoldi C, Zona C, et al. Beta amyloid aggregation inhibitors: small molecules as candidate drugs for therapy of Alzheimer's disease. Curr Med Chem. 2010;17(27):2990-3006.

32. Zalba S, Navarro I, Trocóniz IF, et al. Application of different methods to formulate PEG-liposomes of oxaliplatin: evaluation in vitro and in vivo. Eur J Pharm Biopharm. 2012;81(2):273-280.

33. Ohara Y, Oda T, Yamada K, et al. Effective delivery of chemotherapeutic nanoparticles by depleting host Kupffer cells. Int J Cancer. 2012; 131(10):2402-2410.

34. Andrew PJ, Mayer B. Enzymatic function of nitric oxide synthases. Cardiovasc Res. 1999;43(3):521-531.
35. Afergan E, Ben David M, Epstein H, et al. Liposomal simvastatin attenuates neointimal hyperplasia in rats. AAPS J. 2010;12(2):181-187.

36. Cohen-Sela E, Dangoor D, Epstein H, et al. Nanospheres of a bisphosphonate attenuate intimal hyperplasia. J Nanosci Nanotechnol. 2006;6(9-10):3226-3234.

37. Delgado D, Gascón AR, Del Pozo-Rodríguez A, et al. Dextranprotamine-solid lipid nanoparticles as a non-viral vector for gene therapy: in vitro characterization and in vivo transfection after intravenous administration to mice. Int J Pharm. 2012;425(1-2):35-43.

38. Li S, Ji Z, Zou M, et al. Preparation, characterization, pharmacokinetics and tissue distribution of solid lipid nanoparticles loaded with tetrandrine. AAPS Pharm Sci Tech. 2011;12(3):1011-1018.

39. Schöler N, Olbrich C, Tabatt K, et al. Surfactant, but not the size of solid lipid nanoparticles (SLN) influences viability and cytokine production of macrophages. Int J Pharm. 2001;221(1-2):57-67.

40. Schöler N, Hahn H, Müller RH, Liesenfeld O. Effect of lipid matrix and size of solid lipid nanoparticles (SLN) on the viability and cytokine production of macrophages. Int J Pharm. 2002;231(2):167-176.

41. Teskac K, Kristl J. The evidence for solid lipid nanoparticles mediated cell uptake of resveratrol. Int J Pharm. 2010;390(1):61-69.

42. Reddy LH, Couvreur P. Nanotechnology for therapy and imaging of liver diseases. $J$ Hepatol. 2011;55(6):1461-1466. 


\section{Supplementary table}

Table SI Effect of nanoparticles binding $\beta$-amyloid peptide on production of nitric oxide, cell viability, phosphorylation of eNOS, and intracellular free $\mathrm{Ca}^{2+}$ concentration by cultured endothelial cells and macrophages

\begin{tabular}{|c|c|c|c|c|c|c|c|}
\hline \multirow{2}{*}{$\begin{array}{l}\text { Type of } \\
\text { NP }\end{array}$} & \multirow{2}{*}{$\begin{array}{l}\text { NP } \\
\text { concentration }\end{array}$} & \multicolumn{4}{|c|}{ HUVEC cells } & \multicolumn{2}{|c|}{ Macrophages } \\
\hline & & $\begin{array}{l}\text { Cell } \\
\text { toxicity }\end{array}$ & $\begin{array}{l}\text { NO } \\
\text { production }\end{array}$ & $\begin{array}{l}\text { eNOS } \\
\text { phophorylation }\end{array}$ & $\begin{array}{l}\text { Intracellular } \\
{\left[\mathrm{Ca}^{2+}\right]}\end{array}$ & $\begin{array}{l}\text { Cell } \\
\text { toxicity }\end{array}$ & $\begin{array}{l}\text { NO } \\
\text { production }\end{array}$ \\
\hline \multirow[t]{3}{*}{ Plain LIP } & $6 \mu \mathrm{g} / \mathrm{mL}$ & - & - & - & - & - & - \\
\hline & $30 \mu \mathrm{g} / \mathrm{mL}$ & - & - & - & - & + & - \\
\hline & $120 \mu \mathrm{g} / \mathrm{mL}$ & - & - & - & - & + & - \\
\hline \multirow[t]{3}{*}{ PA-LIP } & $6 \mu \mathrm{g} / \mathrm{mL}$ & - & - & - & - & + & - \\
\hline & $30 \mu \mathrm{g} / \mathrm{mL}$ & - & - & - & - & ++ & - \\
\hline & $120 \mu \mathrm{g} / \mathrm{mL}$ & - & + & + & + & ++ & + \\
\hline \multirow[t]{3}{*}{ CL-LIP } & $6 \mu \mathrm{g} / \mathrm{mL}$ & - & - & - & - & ++ & - \\
\hline & $30 \mu \mathrm{g} / \mathrm{mL}$ & - & - & - & - & ++ & - \\
\hline & $120 \mu \mathrm{g} / \mathrm{mL}$ & - & + & + & + & ++ & + \\
\hline \multirow[t]{5}{*}{ SLN } & $10 \mu \mathrm{g} / \mathrm{mL}$ & ++ & - & & & ++ & - \\
\hline & $50 \mu \mathrm{g} / \mathrm{mL}$ & ++ & - & & & ++ & - \\
\hline & $100 \mu \mathrm{g} / \mathrm{mL}$ & ++ & + & & & +++ & - \\
\hline & $150 \mu \mathrm{g} / \mathrm{mL}$ & ++ & + & & & +++ & - \\
\hline & $1500 \mu \mathrm{g} / \mathrm{mL}$ & ++ & + & & & +++ & + \\
\hline \multirow[t]{5}{*}{ PA-SLN } & $10 \mu g / m L$ & ++ & - & & & ++ & - \\
\hline & $50 \mu \mathrm{g} / \mathrm{mL}$ & ++ & - & & & ++ & - \\
\hline & $100 \mu \mathrm{g} / \mathrm{mL}$ & ++ & - & & & +++ & - \\
\hline & $150 \mu \mathrm{g} / \mathrm{mL}$ & ++ & + & & & +++ & - \\
\hline & $1500 \mu \mathrm{g} / \mathrm{mL}$ & ++ & + & & & +++ & + \\
\hline \multirow[t]{4}{*}{ PACA } & $0.64 \mu \mathrm{g} / \mathrm{mL}$ & - & - & & & - & - \\
\hline & $6.4 \mu \mathrm{g} / \mathrm{mL}$ & - & - & & & - & - \\
\hline & $64 \mu \mathrm{g} / \mathrm{mL}$ & - & - & & & ++ & + \\
\hline & $640 \mu \mathrm{g} / \mathrm{mL}$ & ++ & + & & & ++ & + \\
\hline \multirow[t]{4}{*}{ PEG-PACA } & $0.64 \mu \mathrm{g} / \mathrm{mL}$ & - & - & & & - & - \\
\hline & $6.4 \mu \mathrm{g} / \mathrm{mL}$ & - & - & & & - & - \\
\hline & $64 \mu \mathrm{g} / \mathrm{mL}$ & + & + & & & ++ & + \\
\hline & $640 \mu \mathrm{g} / \mathrm{mL}$ & +++ & + & & & +++ & + \\
\hline
\end{tabular}

Notes: Effect of nanoparticles on cell toxicity: - , no toxic effect;,$+ 10 \%-20 \%$ cell death compared with untreated cells;,$++ 20 \%-50 \%$ cell death compared with untreated cells; +++, 50\%-100\% cell death compared with untreated cells. Effect of nanoparticles on overproduction of nitric oxide: -, no overproduction of nitric oxide after cell treatment with nanoparticles; +, overproduction of nitric oxide after exposure of cells to nanoparticles. Effect of nanoparticles on eNOS phosphorylation: -, no detectable increase in eNOS phosphorylation compared with untreated cells; +, increased eNOS phosphorylation after exposure of cells to nanoparticles. Effect of nanoparticles on intracellular levels of free $\mathrm{Ca}^{2+}:-$, no detectable increase in $\mathrm{Ca}^{2+}$ levels compared with untreated cells; + , increased $\mathrm{Ca}^{2+}$ levels after exposure of cells to nanoparticles. Abbreviations: HUVECs, human umbilical vein endothelial cells; LIP, liposomes; NP, nanoparticles; NO, nitric oxide; PA, phosphatidic acid; CL, cardiolipin; SLN, solid lipid nanoparticles; PEG, poly(ethylene glycol); PACA, poly(alkyl cyanoacrylate); eNOS, endothelial nitric oxide synthase.

International Journal of Nanomedicine

\section{Dovepress}

\section{Publish your work in this journal}

The International Journal of Nanomedicine is an international, peerreviewed journal focusing on the application of nanotechnology in diagnostics, therapeutics, and drug delivery systems throughou the biomedical field. This journal is indexed on PubMed Central,

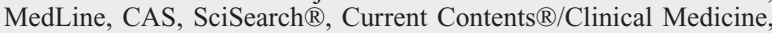

Journal Citation Reports/Science Edition, EMBase, Scopus and the Elsevier Bibliographic databases. The manuscript management system is completely online and includes a very quick and fair peer-review system, which is all easy to use. Visit http://www.dovepress.com/ testimonials.php to read real quotes from published authors. 